\title{
Maternal RNAs encoding transcription factors for germline- specific gene expression in Drosophila embryos
}

\author{
JUN YATSU1,2,\#, MAKOTO HAYASHI 1,2,\#, MASANORI MUKAI ${ }^{3}$, KAYO ARITA ${ }^{4}$, SHUJI SHIGENOBU ${ }^{1,5}$ \\ and SATORU KOBAYASHI $1,2, *$ \begin{abstract}
Myodaiji, Okazaki, ${ }^{2}$ Department of Basic Biology, School of Life Science, Graduate University for Advanced Studies, Myodaiji, Okazaki, ${ }^{3}$ Department of Biology, Faculty of Science and Engineering, Konan University, Kobe,

${ }^{4}$ Clinical Research Center for Blood Diseases, National Hospital Organization Nagoya Medical Center, Nagoya and
\end{abstract} \\ ${ }^{1}$ Okazaki Institute for Integrative Bioscience, National Institute for Basic Biology, National Institutes of Natural Sciences, Higashiyama, \\ ${ }^{5}$ Precursory Research for Embryonic Science and Technology, Japan Science and Technology Agency, Kawaguchi, Saitama, Japan
}

\begin{abstract}
In early Drosophila embryos, germ plasm is localized to the posterior pole region and is partitioned into the germline progenitors, known as pole cells. Germ plasm contains the maternal factors required for germline development. It has been proposed that germline-specific gene expression is initiated by the function of maternal factors that are enriched in the germ plasm. However, such factors have remained elusive. Here, we describe a genome-wide survey of maternal transcripts that encode for transcription factors and are enriched in the germ plasm. We isolated pole cells from blastodermal embryos by fluorescence-activated cell sorting (FACS) and then used these isolated cells in a microarray analysis. Among the 835 genes in the Gene Ontology (GO) category "transcription regulator activity" listed in FlyBase, 68 were found to be predominantly expressed in pole cells as compared to whole embryos. As the early pole cells are known to be transcriptionally quiescent, the listed transcripts are predicted to be maternal in origin. Our in situ hybridization analysis revealed that 27 of the 68 transcripts were enriched in the germ plasm. Among the 27 transcripts, six were found to be required for germline-specific gene expression of vasa and/or nanos by knockdown experiments using RNA interference (RNAi). The identified transcripts encode a transcriptional activator (ovo), components of the transcriptional initiation complexes (Trf2, bip2 and Tif-IA), and the Ccr4-Not complex (CG31716 and I(2)NC136). Our study demonstrates that germ plasm contains maternal transcripts encoding transcriptional regulators for germline-specific gene expression in pole cells.
\end{abstract}

KEY WORDS: germ line, germ plasm, pole cell, transcription factor, Drosophila

\section{Introduction}

Identifying the mechanisms underlying germline establishment is a century-old issue in developmental biology. In the animal species, there are at least two distinct modes of germline establishment (Extavour and Akam, 2003). In certain animal species, germline progenitors are characterized by inheriting a specialized ooplasm, or germ plasm, that contains the maternal factors required for and sufficient for germline development (Beams and Kessel, 1974; Eddy, 1975; Rongo and Lehmann,
1996). In other animal species, the germline is specified by inductive signals from the surrounding tissues (Lawson et al., 1999). It has been known that, irrespective of the modes of germline establishment, vasa (vas) and nanos (nos) genes are commonly expressed in the germline progenitors (Extavour and Akam, 2003). Thus, it is possible that the mechanism underlying vas and nos expression is conserved throughout the animal

Abbreviations used in this paper: GFP, green fluorescent protein; eGFP, enhanced GFP.

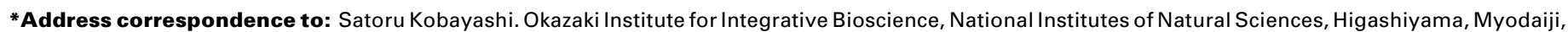
Okazaki 444-8787, Japan. Fax: +81-564-59-5879. e-mail: skob@nibb.ac.jp

\# Note: These authors have contributed equally to this work.
} 


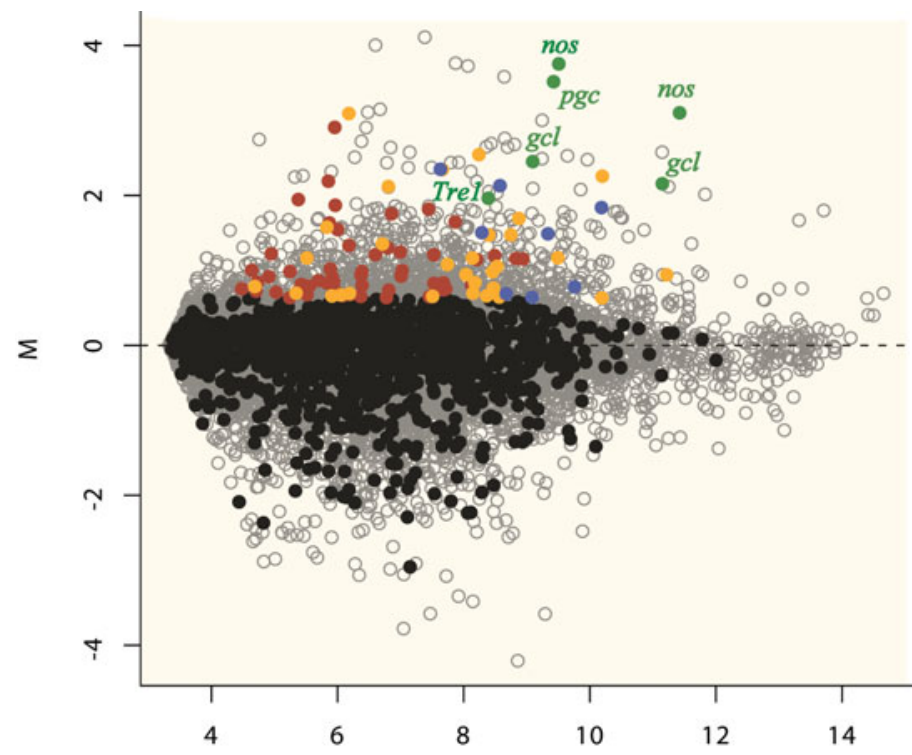

A

pole cell formation (lida and Kobayashi, 1998; Robertson et al., 1999). Likewise, the maternal RNA binding protein Nos is essential to repress mitosis, apoptosis, and somatic differentiation of pole cells (Asaoka-Taguchi etal., 1999; Hayashi et al., 2004; Sato et al., 2007). polar granule component (pgc) RNA is required for pole cell survival (Nakamura et al., 1996; Martinho et al., 2004). Pole cells also require trapped in endoderm-1 (Tre 1), a maternal RNA encoding a G-protein-coupled receptor that is required for their transepithelial movement through the midgut wall (Kunwar et al., 2003). Furthermore, several maternal transcripts enriched in germ plasm have been additionally identified by in situhybridization screens (Szuperák et al., 2005; Sato et al., 2007). However, neither genetic nor molecular screens have yet identified any maternal factors that encode for transcriptional regulators involved in germline-specific pole cell gene expression.

Here, we describe the identification of maternal RNAs that are enriched in the germ plasm and encode for transcription factors. We utilize RNAi knockdown to investigate transcription factor function for germline-specific vas and nos expression in pole cells. Six transcripts were found to be required for vas and/or nos gene expression. These transcripts encode for a transcriptional activator (ovo), for transcriptional initiation complex components (Trf2, bip2 and Tif-IA), and for the Ccr4-Not complex (CG31716 and /(2)NC136). This study provides an important first step toward understanding gene regulation in pole cells and suggests that these identified maternal factors may be involved in germline development by regulating pole cell gene expression.

\section{Results and Discussion}

\section{A screen for candidate transcripts enriched in early pole cells}

To identify novel maternal transcripts enriched in the Drosophilagerm plasm, we compared the transcriptome from pole cells and from whole embryos at stage 4 by microarray analysis. First, fluorescence-activated cell sorting (FACS) was used to isolate pole cells from embryos carrying the transgene EGFP-vasa, which express GFP specifically in the germline. RNA was extracted from the isolated pole cells and from the whole embryos. These RNA isolates were amplified and labeled with Сy3 and Cy5, and hybridized to a microarray containing oligo probes for all of the predicted protein-coding genes in Drosophila genome. After filtering out any probe sets with low quality results, e.g. low signal intensity and high variance between the dye-swap experiments (see Materials and Methods for details), we identified candidate transcripts enriched in pole cells (Fig. 1). In this screen, maternal transcripts known to be enriched in the germ plasm and in pole cells were identified. RNA transcripts for nos, gcl, Tre 1 and pgcwere detected at 13.7-, 5.5-, 4.1- and 11.5-fold higher levels respectively in pole cells when compared to whole embryos (Fig. 1). These results suggest that maternal transcripts enriched in pole cells were successfully identified by the microarray analysis, even though only a single RNA sample was screened in the microarray analysis due to the technical difficulty of obtaining RNA from the sorted pole cells.

In this study, we focused on the genes encoding for transcription factors because they represent probable candidates for maternal regulators of pole-cell gene expression. Among the 835 genes in the Gene Ontology (GO) category "transcription regula-

2001). For example the mitochondrial large ribosomal RNA and the BTB/POZ protein Germ cell-less $(\mathrm{Gcl})$ are both involved in
Germline-specific gene expression is thought to be activated by maternal factors localized in the germ plasm. To date, several maternal factors have been identified whose functions are required for early events in germline development (Mahowald, 
tor activity" (GO:0030528) in FlyBase (http:// flybase.bio.indiana.edu/), 68 were selected on the basis of their higher pole cell to whole embryo ratios and signal intensities in the microarray analysis (Fig. 1, see Materials and Methods for details).

\section{Distribution of the selected transcripts in early embryos}

Because RNA polymerase II-dependent transcription is globally repressed in early pole cells (Seydoux and Dunn, 1997), the 68 transcripts selected from the microarray analysis were predicted to be maternal in origin and present in the germ plasm. As a next step, whole-mount in situ hybridization (WISH) analysis was performed to select for the transcripts that are enriched in germ plasm. We obtained useful expression data for the 65 transcripts (see Materials and Methods), and we found that the transcripts from 27 genes were enriched in the germ plasm of cleavage embryos (Table 1, Fig. 2). Of the selected 27 genes, $63 \%(17 / 27)$ showed high signal intensities in microarray hybridization (A-value $\geq 8.0 ; A=\log _{2} \sqrt{P W}, P=$ pole-cell-signal intensity, $\mathrm{W}=$ whole-embryo-signal intensity), while the majority $(89 \%)$ of the 38 genes not enriched in germ plasm showed low signal intensities (A-value < 8.0) (Fig. 1). Thus, at low expression, differential microarray hybridization levels were influenced by background noise in our microarray analysis.
To validate our WISH data, we compared the expression pattern of the 27 genes with the expression annotation and the representative images in the Fly-FISH (http://flyfish.ccbr.utoronto.ca/) and BDGP Gene Expression Report (http:/ /www.fruitfly.org/cgi-bin/ex/insitu.pl) which include expression data for 3370 and 6138 genes, respectively (Tomancak et al., 2002; Lécuyer et al., 2007). Among the 27 genes, 10 and 15 have been analyzed for their expression by Fly-FISH and BDGP, respectively. Seven out of the 10 and 6 out of the 15 are reported to be expressed in the germ plasm and/or pole cells at stage 45 , and the remaining genes were classified as either "ubiquitously expressed" or "undetectable expression" (Supplementary Table S2). In contrast, among the 38 genes that were identified in our microarray analysis but not selected by our WISH screen, none $(0 / 18$ in Fly-FISH and 0/16 in BDGP) were reported as enriched in either the germ plasm or pole cells (data not shown). These observations suggest that our WISH analysis is almost compatible with those previously performed. Additionally, we succeeded to identify novel transcripts that are enriched in the germ plasm and/or pole cells (Fig. 2, Supplementary Table S2).

Among the identified 27 transcripts, 7 [Arc 70, sd, ovo, meiP26, CG10462, Trf2and Dsp 1] were detectable in pole cells until at least the end of embryogenesis. In contrast, the remaining 20 transcripts [CG10445, bip2, EP2237, CG3136, Tif-1A, Zyx102EF,

TABLE 1

\section{GENES ENCODING THE TRANSCRIPTS ENRICHED IN GERM PLASM}

\begin{tabular}{|c|c|c|c|c|c|c|}
\hline \multirow[b]{2}{*}{ Genes } & \multicolumn{4}{|c|}{$\begin{array}{c}\text { Distribution of } \\
\text { hybridization signal* }\end{array}$} & \multirow[b]{2}{*}{ GO categories (excerpt) } & \multirow[b]{2}{*}{ FlyBase ID } \\
\hline & GP & PC & mPC & gPC & & \\
\hline CG10445 & + & + & - & - & RNA polymerase II transcription termination factor activity & FBgn0037531 \\
\hline $\operatorname{Arc70}$ & + & + & + & \pm & RNA polymerase II transcription mediator activity & FBgn0039923 \\
\hline$s d$ & + & \pm & \pm & + & specific RNA polymerase II transcription factor activity & FBgn0003345 \\
\hline bip2 & + & + & + & - & general RNA polymerase II transcription factor activity & FBgn0026262 \\
\hline EP2237 & + & + & - & - & transcriptional activator activity & FBgn0043364 \\
\hline ovo & + & + & + & + & RNA polymerase II transcription factor activity & FBgn0003028 \\
\hline CG3136 & + & \pm & - & - & transcription factor activity & FBgn0033010 \\
\hline Tif-IA & + & \pm & - & - & RNA polymerase I transcription factor activity & FBgn0032988 \\
\hline Zyx102EF & + & \pm & - & + & transcription regulator activity & FBgn0052018 \\
\hline rgr & + & \pm & - & - & transcription factor activity & FBgn0033310 \\
\hline mei-P26 & + & + & + & + & transcription regulator activity & FBgn0026206 \\
\hline Tra1 & + & + & - & - & transcription cofactor activity & FBgn0033013 \\
\hline CG10462 & + & + & + & + & transcription regulator activity & FBgn0032815 \\
\hline Rel & + & - & - & - & specific RNA polymerase II transcription factor activity & FBgn0014018 \\
\hline NC2alpha & + & - & - & - & transcriptional repressor activity & FBgn0034650 \\
\hline $\operatorname{ref}(2) P$ & + & + & + & - & transcription regulator activity & FBgn0003231 \\
\hline $\mathrm{PCl}$ & + & + & - & - & transcription regulator activity & FBgn0003044 \\
\hline CG31716 & + & + & - & - & transcriptional repressor activity & FBgn0051716 \\
\hline Hcf & + & + & + & - & transcription coactivator activity & FBgn0039904 \\
\hline$H$ & + & \pm & + & - & transcription corepressor activity & FBgn0001169 \\
\hline$z f h 1$ & + & + & - & + & RNA polymerase II transcription factor activity & FBgn0004606 \\
\hline Trf2 & + & + & \pm & + & specific RNA polymerase II transcription factor activity & FBgn0026758 \\
\hline Dsp1 & + & + & + & + & transcription corepressor activity & FBgn0011764 \\
\hline Smox & + & - & - & - & transcription regulator activity & FBgn0025800 \\
\hline CG5640 & + & \pm & - & - & transcriptional repressor activity & FBgn0032207 \\
\hline I(2)NC136 & + & + & - & - & transcription regulator activity & FBgn0033029 \\
\hline$t t k$ & + & - & - & - & specific RNA polymerase II transcription factor activity & FBgn0003870 \\
\hline
\end{tabular}

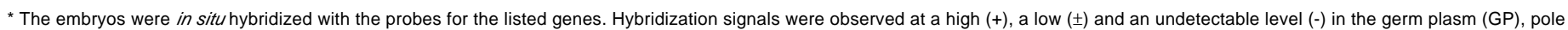
cells at stage $4 / 5(\mathrm{PC})$, migrating pole cells (mPC) and pole cells within the gonads (gPC). 
rgr, Tra1, Rel, NC2alpha, ref(2)P, PCl, CG31716, Hcf, H, zfh1, Smox, CG5640, I(2)NC136 and ttk] were no longer detectable by in situhybridization in pole cells during their migration to the embryonic gonads. However, Zyx102EFand zfh1 were again detected in pole cells within the embryonic gonads, suggesting that these two genes were expressed zygotically within the gonads. All of the genes, except for CG10445and Arc70, were also expressed zygotically in the somatic tissues, such as the midgut, mesoderm, and the central nervous system (Fig. 2).

\section{RNAi screen to determine maternal transcript requirement for germline-specific gene ex- pression}

The 27 maternal transcripts were further screened by RNAi for their possible function in germline-specific gene expression. RNAi has been increasingly exploited to knockdown target RNA levels and to explore gene function in vivo and in cultured cells (Kobayashi et al., 2006). In Drosophila, transgenes expressing double-stranded RNA (dsRNA) are used to knockdown gene function in vivo, and UAS-RNAi lines which target many Drosophilagenes are now readily available (Akasaka et al., 2006; Kobayashi et al., 2006; Yang et al., 2006; Dietzl et al., 2007). Here, however, dsRNA targeting each maternal transcript was injected into cleavage embryos to diminish the activity from each maternal transcript. The germline-specific expression of vas and nos genes in pole cells was then examined. Instead of expressing dsRNAs later in pole cells, this "injection" method takes advantage of the opportunity to target maternal transcripts immediately after oviposition and thus effectively reduce their function (Sato et al., 2007). In normal embryos, zygotic vas and nos expression is initiated in pole cells approximately at stages 9 and 15 , respectively. Their expression continues to be detectable until at least the end of embryogenesis. Hence, vas and nos gene expression in dsRNA-injected embryos was examined at stage $15-16$ [26 $\mathrm{hr}$ after egg laying (AEL) at $18^{\circ} \mathrm{C}$ ].

DsRNA-injected embryos were allowed to develop at $18^{\circ} \mathrm{C}$ until $26 \mathrm{hr} A E L$, and then RNAibased screen in two steps. First, vas and nos expression was examined promptly and without regard to their developmental status in order to identify required candidate transcripts (Table 2 ). Second, a detailed analysis of the dsRNA-induced phenotype against the candidate transcripts was performed with regard to embryonic development, pole cell development, pole cell transcriptional ability, and expression of the germlinespecific genes in pole cells (Tables $3-5$ ). Taken together, these two steps identified six transcripts whose dsRNAs significantly decreased the per-
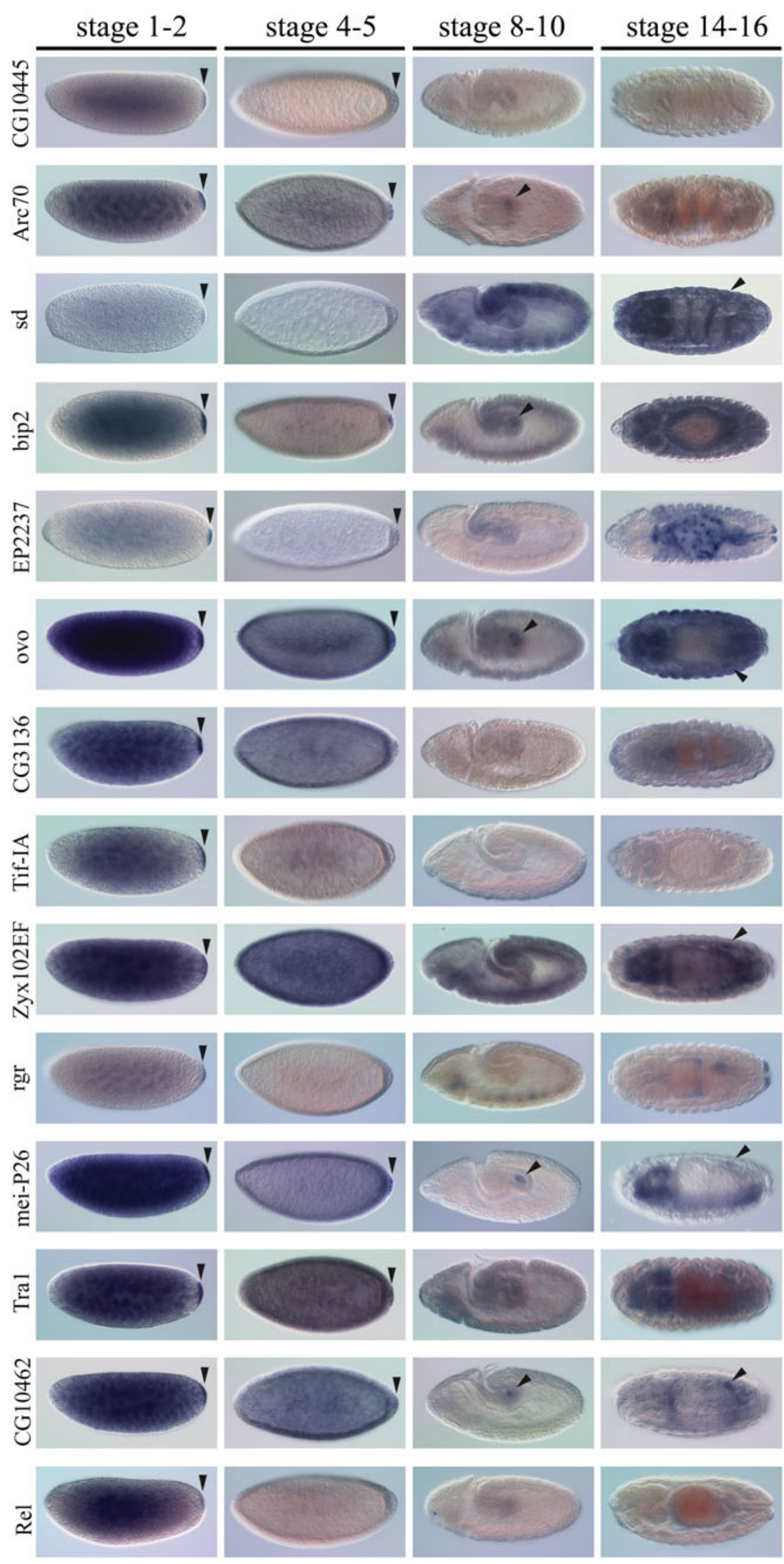

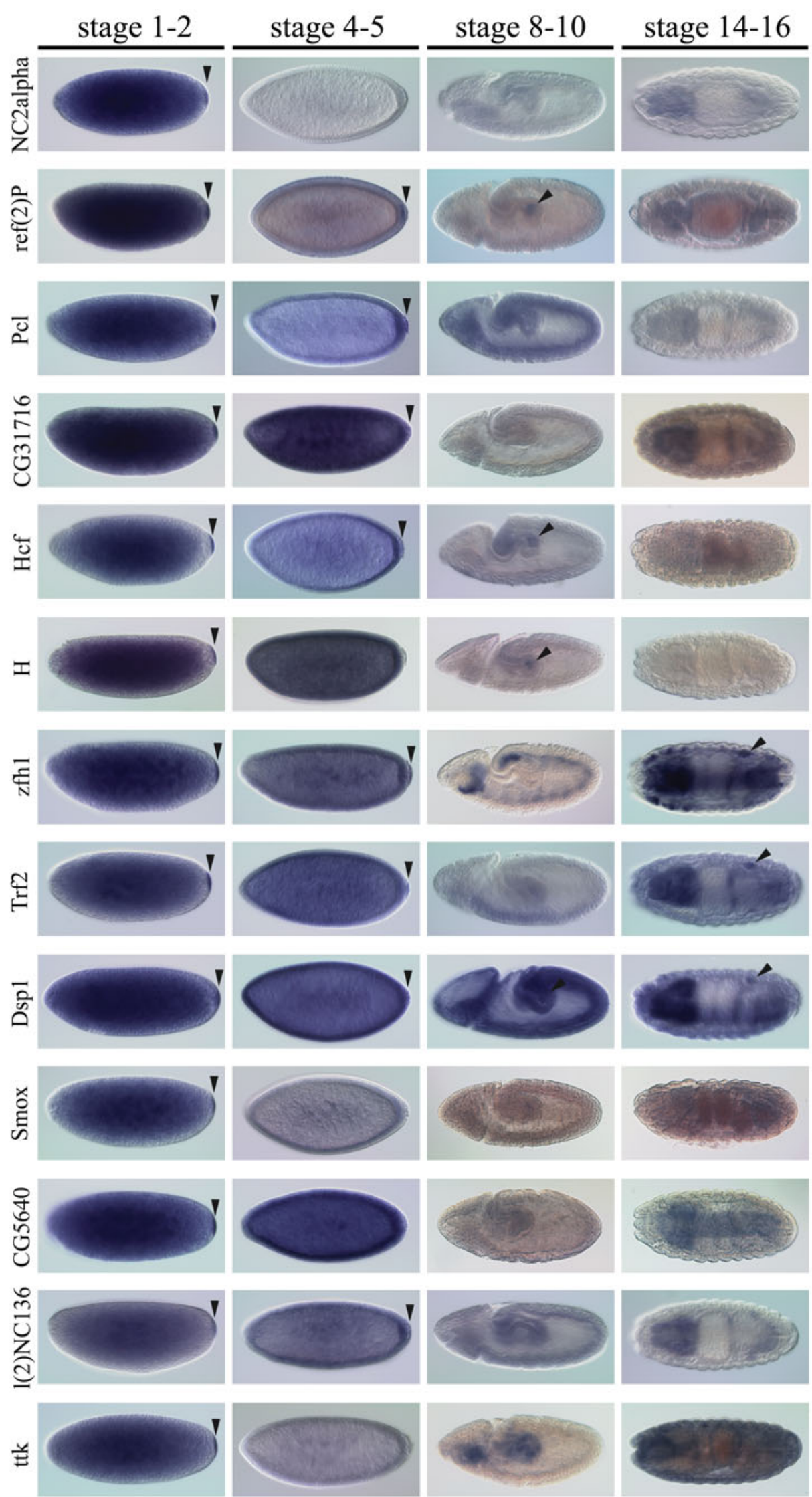
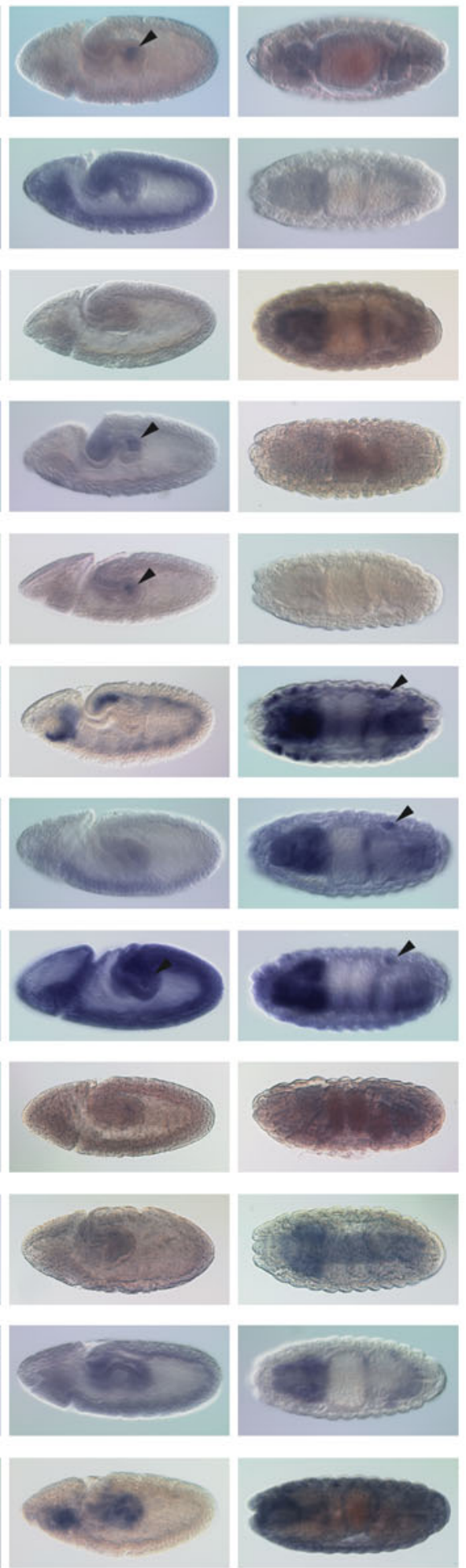

centage of the stage 15-16 embryos expressing vasand/or nosin pole cells (Table 3, Fig. 3).

A significant reduction in the amount of the six transcripts were evident, when their dsRNAs were injected into embryos (Supplementary Fig. S1). Injection of dsRNAs targeting the transcripts of bip2, ovo, CG31716 and Trf2 repressed both vasand nosexpression. /(2)NC136dsRNA repressed vas expression, while Tif-IA dsRNA suppressed nosexpression in pole cells. None of the six dsRNAs against these transcripts except CG31716and Trf2 affected embryonic development (Table 4 ), including pole cell formation, pole cell migration, and gonad formation. The expected population of pole cells was incorporated within the embryonic gonads of the injected embryos at stage 15-16 (Fig. 3 , data not shown). Table 4 shows that the injection of CG31716 dsRNA slightly reduced the percentage of embryos developing to stage 15-16, but, in the surviving embryos, the pole cells colonized normally within the gonads (Fig. 3, data not shown). Although Trf2 dsRNA injection retarded embryonic development during germ band shortening in $60-90 \%$ of the embryos (Table 3-5), the embryos that survived to stage 15-16 showed no defects in pole cell development (Fig. 3, data not shown). Pole cells in the stage 15-16 embryos that were injected with each of the six dsRNA had retained a normal ability to express the UAS-lacZtransgene under maternally supplied Gal4 (Table 5). The above data suggest that repression of the germline-specific gene expression is not caused by an indirect effect of the injected dsRNAs on the embryonic development or on the transcriptional machinery.

\section{Overview of the identified transcripts}

The above data suggest that vas and nos expression is regulated by the combination of transcription factors encoded by the germ plasm-enriched maternal transcripts. The identified transcripts encode for a transcriptional activator ( ovo), for components of the transcriptional initiation complexes (Trf2, bip2 and Tif-IA), and for the

Fig. 2. Expression of the 27 transcripts in embryos. Embryos were probed byin situ hybridization for the gene shown on the left. Developmental stages are shown at the top. Arrowheads show the germ plasm and pole cells with a strong signal (+ in Table 1). Anterior is to the left. 
TABLE 2

EXPRESSION OF VAS AND NOS RNA IN POLE CELLS OF THE dSRNA-INJECTED EMBRYOS

\begin{tabular}{|c|c|c|c|c|c|c|c|c|c|c|}
\hline \multirow[b]{2}{*}{ dsRNA* } & \multicolumn{5}{|c|}{ No. of embryos expressing vas in pole cells ${ }^{\$}$} & \multicolumn{5}{|c|}{ No. of embryos expressing nos in pole cells ${ }^{\$}$} \\
\hline & $\begin{array}{c}\text { No. of } \\
\text { embryos } \\
\text { examined }\end{array}$ & $+(\%)$ & & $\pm(\%)$ & $-(\%)$ & $\begin{array}{l}\text { No. of } \\
\text { embryos } \\
\text { examined }\end{array}$ & $+(\%)$ & & $\pm(\%)$ & $-(\%)$ \\
\hline$-(D W)$ & 208 & $176(84.6)$ & & $14(6.7)$ & $18(8.7)$ & 172 & $134(74.9)$ & & $21(12.2)$ & 17 (9.9) \\
\hline CG10445 & 25 & $21(84.0)$ & \# & $4(16.0)$ & $0(0)$ & 29 & $23(79.3)$ & \# & $0(0)$ & $6(20.7)$ \\
\hline Arc70 & 21 & 15 (71.4) & \# & $5(23.8)$ & $1(4.8)$ & 24 & $18(75.0)$ & $\#$ & $3(12.5)$ & $3(12.5)$ \\
\hline sd & 32 & $25(78.1)$ & $\#$ & $6(18.8)$ & $1(3.1)$ & 37 & $26(70.3)$ & $\#$ & $8(21.6)$ & $3(8.1)$ \\
\hline bip2 & 31 & $16(51.6)$ & $\# \#$ & $14(45.2)$ & $1(3.2)$ & 28 & $11(39.3)$ & \#\#\# & $17(60.7)$ & $0(0)$ \\
\hline$E P 2237$ & 35 & $32(91.4)$ & $\#$ & $2(5.7)$ & $1(2.9)$ & 33 & $29(87.9)$ & $\#$ & $4(12.1)$ & $0(0)$ \\
\hline ovo & 23 & 7 (30.4) & \#\#\# & $8(34.8)$ & $8(34.8)$ & 28 & $13(46.4)$ & $\# \# \#$ & $4(14.3)$ & 11 (39.3) \\
\hline CG3136 & 20 & $18(90.0)$ & $\#$ & $2(10.0)$ & $0(0)$ & 33 & 24 (72.7) & $\#$ & $5(15.2)$ & 4 (12.1) \\
\hline Tif-IA & 30 & $22(73.3)$ & $\#$ & $8(26.7)$ & $0(0)$ & 32 & $17(53.1)$ & \#\#\# & $11(34.4)$ & $4(12.5)$ \\
\hline Zyx102EF & 25 & $23(92.0)$ & $\#$ & $1(4.0)$ & $1(4.0)$ & 17 & $16(94.1)$ & $\#$ & $1(5.9)$ & $0(0)$ \\
\hline$r g r$ & 36 & $32(88.9)$ & $\#$ & $0(0)$ & 4 (11.1) & 22 & $19(86.4)$ & $\#$ & $3(13.6)$ & $0(0)$ \\
\hline mei-P26 & 29 & $22(75.9)$ & $\#$ & $4(13.8)$ & $3(10.3)$ & 14 & 9 (64.3) & $\#$ & $2(14.3)$ & $3(21.4)$ \\
\hline Tra1 & 19 & 17 (89.5) & $\#$ & $1(5.3)$ & 1 (5.3) & 21 & $16(76.2)$ & $\#$ & $0(0)$ & $5(23.8)$ \\
\hline CG10462 & 28 & $27(96.4)$ & $\#$ & $1(3.6)$ & $0(0)$ & 31 & $26(83.9)$ & $\#$ & $0(0)$ & $5(16.1)$ \\
\hline Rel & 28 & $28(100)$ & $\# \#$ & $0(0)$ & $0(0)$ & 39 & 34 (87.2) & $\#$ & $2(5.1)$ & $3(7.7)$ \\
\hline NC2alpha & 29 & $24(82.8)$ & $\#$ & $5(17.2)$ & $0(0)$ & 30 & $24(80.0)$ & $\#$ & $3(10.0)$ & $3(10.0)$ \\
\hline $\operatorname{ref}(2) P$ & 30 & 22 (73.3) & $\#$ & $6(20.0)$ & $2(6.7)$ & 26 & $19(73.1)$ & $\#$ & $3(11.5)$ & $4(15.4)$ \\
\hline $\mathrm{PCl}$ & 34 & $30(88.2)$ & $\#$ & $3(8.8)$ & $1(2.9)$ & 26 & $21(80.8)$ & $\#$ & $2(7.7)$ & $3(11.5)$ \\
\hline CG31716 & 27 & 16 (59.3) & \#\#\# & $5(18.5)$ & $6(22.2)$ & 23 & $6(26.1)$ & \#\#\# & $5(21.7)$ & $12(52.2)$ \\
\hline Hcf & 31 & 29 (93.5) & $\#$ & $1(3.2)$ & $1(3.2)$ & 27 & 25 (92.6) & $\#$ & $1(3.7)$ & 1 (3.7) \\
\hline$H$ & 31 & 26 (83.9) & $\#$ & $5(16.1)$ & $0(0)$ & 31 & $26(83.9)$ & $\#$ & $1(3.2)$ & $4(12.9)$ \\
\hline zfh1 & 32 & 26 (81.3) & $\#$ & $1(3.1)$ & $5(15.6)$ & 30 & $21(70.0)$ & $\#$ & $2(6.7)$ & 7 (23.3) \\
\hline Trf2 & 30 & $0(0)$ & \#\#\# & $0(0)$ & $30(100)$ & 14 & $6(42.9)$ & $\# \# \#$ & $2(14.3)$ & 6 (42.9) \\
\hline Dsp1 & 32 & $28(87.5)$ & $\#$ & $0(0)$ & $4(12.5)$ & 20 & $13(65.0)$ & $\#$ & $3(15.0)$ & $4(20.0)$ \\
\hline Smox & 34 & $26(76.5)$ & $\#$ & 7 (20.6) & $1(2.9)$ & 25 & $19(76.0)$ & $\#$ & $4(16.0)$ & $2(8.0)$ \\
\hline CG5640 & 31 & $20(64.5)$ & \#\#\# & $10(32.3)$ & $1(3.2)$ & 21 & $19(90.5)$ & $\#$ & $0(0)$ & $2(9.5)$ \\
\hline I(2)NC136 & 35 & $14(40.0)$ & \#\#\# & $13(37.1)$ & $8(22.9)$ & 34 & 31 (91.2) & $\#$ & $2(5.9)$ & 1 (2.9) \\
\hline ttk & 38 & 30 (78.9) & $\#$ & $8(21.1)$ & $0(0)$ & 30 & $27(90.0)$ & $\#$ & $3(10.0)$ & $0(0)$ \\
\hline
\end{tabular}

* $y$ wembryos were used as recipients for dsRNA microinjection.

$\$$ The injected embryos were stained for vas or nos RNA. No. of the embryos expressing vas or nos RNA in pole cells at a high (+), a low ( \pm ) and an undetectable level (-) are shown.

$\# \mathrm{P}>0.05, \# \# 0.05>\mathrm{P}>0.01, \# \# \mathrm{P}<0.01$; Significance was calculated vs. DW-injected control by using Fisher's exact probability test.

Ccr4-Not complex (CG31716 and /(2)NC136). It is worthwhile to note that this screen identified at least two genes, ovo and Trf2, that have been reported to be required for oogenesis. Genetic screens have identified many maternally acting genes required for early germline development (Mahowald, 2001). However, these screens could only recover mutations that did not affect oogenesis, and therefore failed to identify many maternal genes that play a critical role both in oogenesis and embryonic germline development. In this study, we injected dsRNA into early embryos to examine the role of maternal transcripts in germline-specific gene expression. This method enabled us to circumvent the oogenesis defects and screen for phenotypes in embryos. Detailed functions of the identified six genes are discussed below.

\section{A transcriptional activator, ovo}

The maternal ovo transcript was enriched in the germ plasm and was required for vasand nosexpression in pole cells. The ovo gene encodes for a developmentally regulated, DNA-binding, $\mathrm{C}_{2} \mathrm{H} 2 \mathrm{Zn}$-finger protein that is involved in oogenesis (Oliver et al., 1987; Mével-Ninio et al., 1991; Staab and Steinmann-Zwicky, 1996) and in denticle formation in the epidermal cells (Wieschaus et al., 1984). The ovo gene produces at least three alternate isoforms. Ovo-A and Ovo-B function as a negative and a positive transcriptional regulator in the germline, respectively (Andrews et al., 2000). Ovo-Svb is expressed in the epidermal cells and is required for their differentiation (Payre et al., 1999; Delon et al., 2003). Ovo-B protein activates transcription from the ovarian tumor (otu) and ovo-B promoters in a germline-specific manner via binding to the short regions proximal to their transcriptional start site (Lü and Oliver, 2001; Bielinska et al., 2005). Ovo-B binding to the core promoter region suggests that this protein could interact with the initiation complex TFIID at the same region, either directly or indirectly (Lü and Oliver, 2001). Thus, we postulate that Ovo-B, along with TFIID components, initiates germline-specific expression of vas and nos in pole cells.

The role of maternal ovo in germline development remains elusive, since ovo dsRNA injection caused lethality at the end of embryogenesis due to the defect in epidermal differentiation (data not shown) which requires zygotic ovo function (Oliver et al., 1987). Embryos injected with ovo dsRNA did not show any deleterious defects in pole cell development during embryogenesis. Thus, we speculate that the pole cells with reduced maternal ovo activity may be impaired in their post-embryonic development. Future work is needed to test this consideration by transplanting the pole cells with reduced ovoactivity into normal hosts.

\section{Components of the transcriptional initiation complex}

In the fly, frog, and mouse, Trf2is predominantly expressed in the germline cells during gametogenesis in both females and males (Kopytova et al., 2006; Xiao et al., 2006). Trf2 expression is required for proper Drosophila development of both oocytes and spermatocytes (Kopytova et al., 2006) and for spermatogenesis in mice (Zhang et al., 2001). Although Trf2 is additionally required for somatic development in Drosophilaembryos (Kopytova et al., 2006), its function in the germline is evolutionarily conserved. 
TABLE 3

\section{EXPRESSION OF VAS AND NOS RNA IN POLE CELLS OF THE dSRNA-INJECTED EMBRYOS}

\begin{tabular}{|c|c|c|c|c|c|c|}
\hline \multirow[b]{2}{*}{ dsRNA* } & \multirow[b]{2}{*}{ No.of injected embryos } & \multirow[b]{2}{*}{ No.of surviving embryos\$ } & \multicolumn{4}{|c|}{ No. of embryos expressing vas in pole cells ${ }^{\text {ss }}$} \\
\hline & & & $+(\%)$ & & $\pm(\%)$ & $-(\%)$ \\
\hline GFP & 62 & 55 & $47(85.5)$ & & $6(10.9)$ & $1(3.6)$ \\
\hline bip2 & 54 & 41 & $19(46.3)$ & \#\# & $17(41.5)$ & $5(12.2)$ \\
\hline ovo & 77 & 61 & $22(36.1)$ & $\#$ & $17(27.9)$ & $22(36.1)$ \\
\hline Tif-IA & 65 & 55 & $42(76.4)$ & $\#$ & $10(18.2)$ & $3(5.5)$ \\
\hline CG31716 & 62 & 40 & $12(30.0)$ & $\#$ & $14(35.0)$ & $14(35.0)$ \\
\hline Trf2 & 102 & 20 & $5(25.0)$ & $\# \#$ & $3(15.0)$ & $12(60.0)$ \\
\hline I(2)NC136 & 78 & 72 & $12(16.7)$ & $\# \#$ & $24(33.3)$ & $36(50.0)$ \\
\hline
\end{tabular}

Expression of nos

\begin{tabular}{|c|c|c|c|c|c|c|}
\hline \multirow[b]{2}{*}{ dsRNA* } & \multirow[b]{2}{*}{ No.of injected embryos } & \multirow[b]{2}{*}{ No.of surviving embryos $\$$} & \multicolumn{4}{|c|}{ No. of embryos expressing nos in pole cells ${ }^{\text {SS }}$} \\
\hline & & & $+(\%)$ & & $\pm(\%)$ & $-(\%)$ \\
\hline GFP & 57 & 48 & $37(77.1)$ & & $5(10.4)$ & $6(12.5)$ \\
\hline bip2 & 47 & 40 & $19(47.5)$ & \#\# & $10(25.0)$ & $11(27.5)$ \\
\hline ovo & 68 & 59 & $21(35.6)$ & $\# \#$ & $15(25.4)$ & $23(39.0)$ \\
\hline Tif-IA & 57 & 43 & $13(30.2)$ & $\# \#$ & $10(23.3)$ & $20(46.5)$ \\
\hline CG31716 & 64 & 36 & $9(25.0)$ & $\# \#$ & $3(8.3)$ & $24(66.7)$ \\
\hline Trf2 & 104 & 18 & $5(27.8)$ & \#\# & $2(11.1)$ & $11(61.1)$ \\
\hline I(2)NC136 & 82 & 64 & $47(73.4)$ & $\#$ & $10(15.6)$ & $7(10.9)$ \\
\hline
\end{tabular}

* $y \mathrm{w}$ embryos were used as recipients for dsRNA microinjection.

$\$$ No. of the injected embryos normally developing to stage $15 / 16$ were scored.

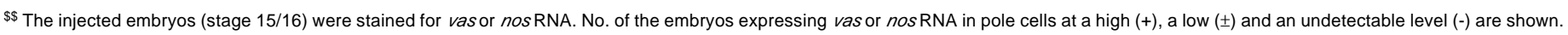
$\# \mathrm{P}>0.05, \# \mathrm{P}<0.01$; Significance was calculated vs. GFP control by using Fisher's exact probability test.

Trf2encodes a TATA box-binding protein (TBP)-related factor (Rabenstein etal., 1999). TBP and TBP-associated factors (TAFs) are known to be components of an initiation complex that recognizes the core promoter sequences (Tjian and Maniatis, 1994; Bell and Tora, 1999). Recent data suggest that Trf2 is involved in the formation of a TFIID-like complex to regulate the expression of a set of genes in a cell-type-specific manner (Hochheimer et al., 2002). Trf2 has been shown to associate with restricted loci on chromosomes at sites different from those of TBP (Rabenstein et al., 1999). Furthermore, the TRF2-containing complex includes components of the chromatin-remodeling complex, NURF, and other proteins that might be involved in chromatin reorganization (Hochheimer et al., 2002). Considering that the trf2 transcript is enriched in germ plasm and is required for vasand nosexpression in pole cells, it is reasonable to speculate that Trf2 may regulate germline-specific genes via the rearrangement of chromatin organization and/or the formation of distinctive TFIID-like complexes.

This idea is supported by the observation that the transcript encoding one of the TAFs, Bric-a-brac interacting protein 2 (BIP2, also called as TAFII155), is enriched in the germ plasm (Fig. 2) and is required for vas and nos expression in pole cells (Fig. 3,

TABLE 4

\section{VIABILITY OF THE EMBRYOS INJECTED WITH dsRNAS}

\begin{tabular}{lcrrr} 
dsRNA $^{*}$ & No.of injected embryos & \multicolumn{4}{c}{ No.of surviving embryos } \\
\hline GFP & 119 & 103 & $(86.6)$ & $\#$ \\
bip2 & 101 & 81 & $(80.2)$ & $\#$ \\
ovo & 145 & 120 & $(82.8)$ & $\#$ \\
Tif-IA & 122 & 98 & $(80.3)$ & $\#$ \\
CG31716 & 126 & 76 & $(60.3)$ & $\#$ \\
Trf2 & 206 & 38 & $(18.4)$ & $\#$ \\
I(2)NC136 & 160 & 136 & $(85.0)$ & $\#$ \\
\hline
\end{tabular}

* $y w$ embryos were used as recipients for dsRNA microinjection.

$\$$ No. of the injected embryos normally developing to stage $15 / 16$ were scored.

$\# \mathrm{P}>0.05, \# \# \mathrm{P}<0.01$; Significance was calculated vs. GFP control by using Fisher's exact probability test.
Table 3). TAFs have been known to act as specific coactivators by interacting with transcriptional activators, and TAFs contribute to promoter recognition and selectivity (Verrijzer et al., 1994; Burke and Kadonaga, 1997). BIP2 was first identified as a partner of the Bric à brac 2 (Bab2) protein (Pointud et al., 2001). BAB2 interacts with BIP2 via BTB/POZ domains, and these two proteins colocalize at transcriptionally active regions of polytene chromosomes (Pointud et al., 2001). BAB2 acts as a developmentally regulated transcriptional activator involved in the morphogenesis of the somatic components of adult ovaries (Couderc et al., 2002). Although the transcriptional activators interacting with BIP2 in early pole cells remain unknown, the above observations suggests that the TFIID-like complex containing TRF2 and BIP2 is involved in the initiation of germline-specific gene expression.

\section{Components of Ccr4-Not complex}

Here, we show that transcripts from CG31716 and I(2)NC136 are both enriched in the germ plasm and required for vas expression in pole cells. CG31716 and /(2)NC136 encode for the proteins NOT4 and NOT3/5, respectively, and both are components of the Ccr4-NOT complex (Collart, 2003). The Ccr4-Not complex is evolutionarily conserved from yeast to human. By potentially interacting with many different proteins, the Ccr4-NOT complex regulates various cellular functions, including transcriptional initiation, RNA metabolism, and protein modification (Collart, 2003). In yeast, NOT5 of the Ccr4-NOT complex can associate with promoters and is involved in transcriptional regulation by interacting with TAF1 (Deluen et al., 2002). Although transcriptional regulation by the Ccr4-NOT complex remains unclear in Drosophila, it is possible that this complex may be directly responsible for vas transcription. Alternatively, it is also possible that the Ccr4-NOT complex is involved in RNA turnover or in the translational regulation that is required for vas expression in pole cells, because the Twin/Ccr4-NOT complex is required for these molecular events during Drosophila development (Morris et al., 
Expression of vasa
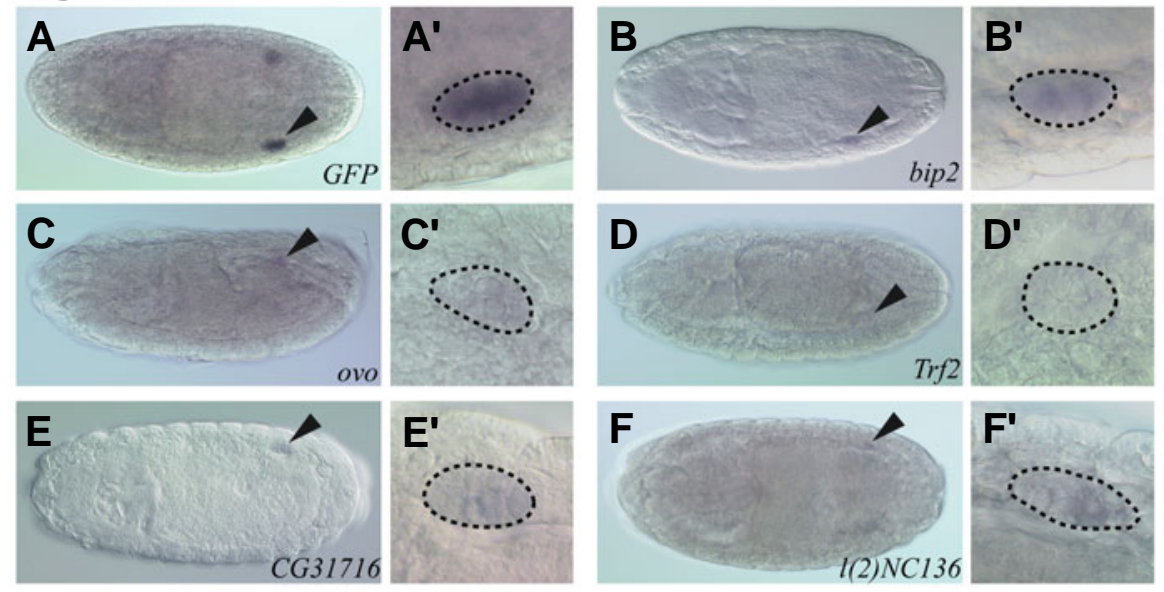

\section{Expression of nanos}
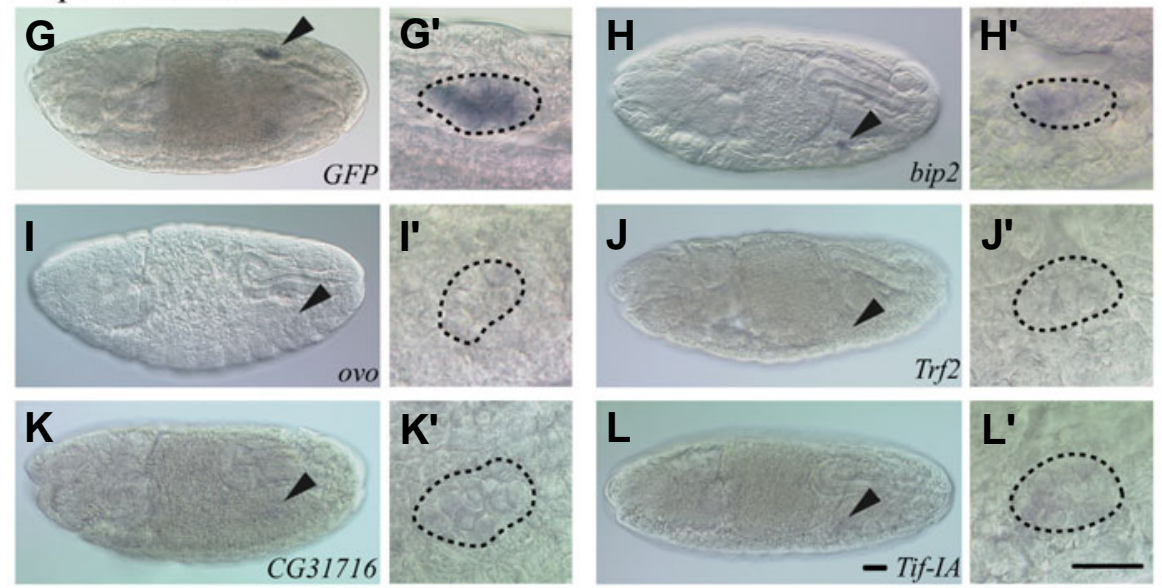
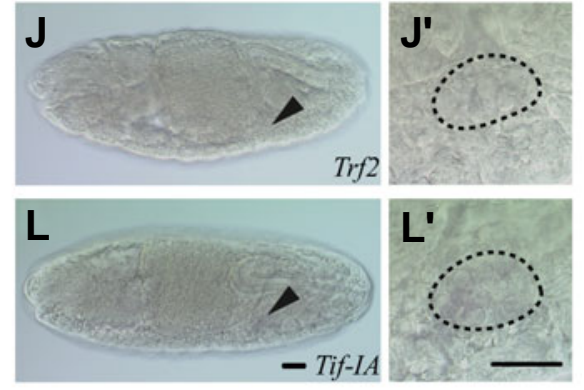

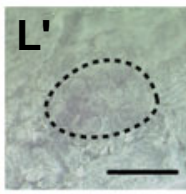

Fig. 3. vas and nos expression in dsRNA-injected embryos. $(\mathbf{A}, \mathbf{G})$ vas $(A)$ and nos expression $(G)$ in the stage-15/16 control embryos injected with dsRNAs for GFP. (B-F and $\mathbf{H}-\mathbf{L})$ Expression of vas $(B-F)$ and nos $(H-L)$ in the stage-15/16 embryos injected with dsRNAs for ovo (B,H), CG31716 (C,I), bip2 (D,J), Trf2 (E,L), I(2)NC136 (F) and Tif-IA (K). ( $\mathbf{A}^{\prime}$-L') Higher magnification images of the embryonic gonads shown in (A-L). Anterior is to the left. Arrowheads in (A-L) point to the gonads. Scale bars, $20 \mu \mathrm{m}$.

otherwise inhibits vas expression in pole cells (Sano et al., 2001). Thus, it is likely that the Ccr4-NOT complex regulates vas expression via Nos-dependent translational repression.

Our results show that injection of the dsRNA for CG31716 but not for I/2)NC136, also affects nos expression in pole cells (Table 3). Perhaps CG31716 has another role in nos expression that is independent of Ccr4-NOT function. Alternatively, it is also possible that pole cells express a gene which shares a redundant function with /(2)NC136 in order to regulate nos expression.

\section{A transcriptional initiation factor for RNA polymerase I}

We found that Tif-IA RNA is enriched in pole cells and is required for nos expression but not vas expression. Tif-IA encodes a Drosophila ortholog of yeast Rrn3p and mammalian TIF-IA, both of which are the initiation factor for RNA polymerase I (RNA poll) (Moss and Stefanovsky, 2002; Grummt, 2003). TIF-IA acts as the key regulator for rRNA transcription by recruiting RNA poll into the rRNA promoter pre-initiation complex, and the interaction between TIF-IA and RNA poll is regulated by various pathways linking biosynthetic activities (Moss and Stefanovsky, 2002; Grummt, 2003). In early pole cells, RNA polll-dependent transcription is globally inhibited by maternal Pgc (Martinho et al., 2004), but RNA poll-dependent transcription remains active (Seydoux and Dunn, 1997). Furthermore, the observed rate of protein synthesis is higher in pole cells than in the rest of somatic

TABLE 5

EXPRESSION OF $\beta$-GAL RNA IN POLE CELLS OF THE dsRNA-INJECTED EMBRYOS

\begin{tabular}{|c|c|c|c|c|c|c|}
\hline \multirow[b]{2}{*}{ dsRNA* } & \multirow[b]{2}{*}{ No. of injected embryos } & \multirow[b]{2}{*}{ No. of surviving embryos } & \multicolumn{4}{|c|}{ No. of embryos expressing $\beta$-gal in pole cells ${ }^{s}$} \\
\hline & & & $+(\%)$ & & $\pm(\%)$ & $-(\%)$ \\
\hline GFP & 42 & 36 & $26(72.2)$ & & $3(8.3)$ & $7(19.4)$ \\
\hline bip2 & 32 & 26 & $22(84.6)$ & $\#$ & $4(15.4)$ & $0(0)$ \\
\hline ovo & 30 & 26 & $21(80.8)$ & $\#$ & $2(7.7)$ & $3(11.5)$ \\
\hline Tif-IA & 37 & 34 & 24 (70.6) & \# & $2(5.9)$ & $8(23.5)$ \\
\hline CG31716 & 37 & 28 & $21(75.0)$ & $\#$ & $2(7.1)$ & $5(17.9)$ \\
\hline Trf2 & 39 & 15 & $12(80.0)$ & $\#$ & $3(20.0)$ & $0(0)$ \\
\hline I(2)NC136 & 42 & 36 & $27(75.0)$ & \# & $2(5.6)$ & $7(19.4)$ \\
\hline
\end{tabular}

* The embryos produced from nosGa/4:VP16 females crossed with UAS-lacZ males were used as recipients for dsRNA microinjection.

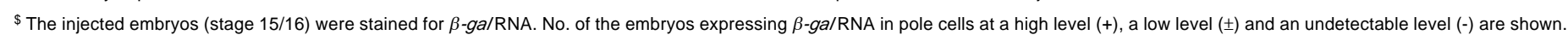

\# $\mathrm{P}>0.05$; Significance was calculated vs. GFP control by using Fisher's exact probability test. 
region in blastodermal embryos (Zalokar, 1976). Thus, we suggest that the pole cell-enriched Tif-IARNA could then upregulate rRNA transcription and protein synthesis in these cells. It is possible that zygotic expression of nos requires a higher rate of protein synthesis than that of vas.

\section{Conclusion}

In this study, we performed a genome-wide survey of the maternal transcripts that are enriched in the germ plasm and that encode for transcriptional regulators. We identified 27 maternal transcripts based on microarray and in situ hybridization data. These results will allow us to understand the molecular basis for germ plasm function, although elucidation of specific processes regulated by each of the identified genes awaits future genetic analyses. We further utilized RNAi knockdown to investigate the role of the identified transcripts in germline-specific gene expression. Six transcripts were found to be required for vas and/or nos expression. This study demonstrates that the germ plasm contains maternal RNAs encoding for transcription factors that are required for germline-specific gene expression in pole cells.

\section{Materials and Methods}

\section{Fly stocks}

Pole cells were isolated from EGFP-vas embryos by FACS. This method efficiently enables us to obtain fractions highly enriched for pole cells (Shigenobu et al., 2006). For in situ hybridization and RNAi analyses, $y w$ files were used. To examine lacZexpression in pole cells, the nosGal4:VP16 and UAS-lacZ lines were used (Van Doren et al., 1998). Flies were raised on a standard Drosophila medium at $25^{\circ} \mathrm{C}$. Embryos were staged according to Campos-Ortega and Hartenstein (1997).

\section{Microarray analysis}

Total RNA was extracted from pole cells isolated from the stage 4 syncytial-blastoderm embryos as described (Shigenobu et al., 2006). As a reference, total RNA was also extracted from stage 4 whole embryos using an RNeasy Mini kit (QIAGEN). Transcript profiles between these RNA samples were then compared by microarray analysis which was performed as described (Sato et al., 2007). Extracted RNA was amplified as cRNAs labeled with cyanine-3 CTP (Cy3) and cyanine-5 CTP (Cy5) using Agilent Low RNA Input Fluorescent Linear Amplification Kit (Agilent Technologies, Palo Alto, CA). Custommade 22K 60-mer oligo microarrays (Agilent) that contain 21,925 probes representing almost all of the predicted Drosophila transcripts were used (Sato et al., 2007) (GPL4336). Each array was hybridized with $1 \mu \mathrm{g}$ of both Cy3-labeled and Cy5-labeled cRNA and washed according to the Agilent protocol. The dye-swap experiment was also carried out. Subsequently, the arrays were scanned with a G2565BA Microarray Scanner System (Agilent). Data were analyzed using the Feature Extraction 7.1 software (Agilent). LOWESS (20\%) normalization was applied to the data using GeneSpring software (Agilent). The probe sets with low signal intensity (normalized value $<10$ ) or with high variance between the dye-swap experiments (variance between Cy3/ Cy5 and Cy5/Cy3 ratios $>75 \%$ ) were excluded, and data for 18,205 probes was used for the subsequent analysis. The data will be deposited in GEO under Accession No. GSE9679.

We selected 735 as "candidate transcripts enriched in pole cells "based on their differential microarray hybridization levels (pole cell to whole embryo ratios $\geq 1.56$; when dual microarray probes were designed to hybridize single transcripts, the higher ratios were used for the selection). Among them, 68 were classified in the GO category "transcriptional regulator activity" in FlyBase (Release 3.1). GO annotation was based on the gene association file (version 2004-7) provided by GO consortium (http://www.geneontology.org/). These selected genes showed a wide variety of pole cells to whole embryo ratios ranging from 1.56 to 8.60 .

\section{In situ hybridization}

Whole-mount in situ hybridization was essentially performed as described (Mukai et al., 2006). DIG-labeled antisense RNA probes were synthesized with T3 RNA polymerase from flanked PCR products amplified from pBluescript SK(+) containing the cDNA fragments and with T7 and T3 primers. The cDNA fragments corresponding to the identified 68 transcripts were amplified from an embryonic cDNA library (Brown and Kafatos, 1988) by using the primer pairs listed in Supplementary Table S1. Each primer pair was designed to amplify approximately $1 \mathrm{~kb}$ of cDNA fragment corresponding to a 3'-portion of the open reading frame. Under the conditions used, we failed to amplify the cDNAs corresponding to Doc1, CG3711, and CG31782. Thus, we examined the distribution of the other 65 transcripts by whole-mount in situ hybridization.

The probe for lacZ $(1.1 \mathrm{~kb})$ was synthesized as previously described (Fatchiyah Zubair et al., 2006).

Signal detection was carried out using an alkaline phosphataseconjugated anti-DIG Fab fragment (Roche). Color development was performed using $0.45 \mathrm{mg} / \mathrm{ml} \mathrm{NBT}$ and $0.18 \mathrm{mg} / \mathrm{ml} \mathrm{BCIP}$ at $25^{\circ} \mathrm{C}$ for 1 $6 \mathrm{hr}$ in the dark.

\section{Microinjection of dsRNAs}

Template DNA fragments flanked by T7 and T3 promoter sequences at each end were amplified from the same cDNA clones used for in situ hybridization using the primer pair

5'-TAATACGACTCACTATAGGG-3' and

5-GTAATACGACTCACTATAGGGCTCACTAAAGGGAACAAAAGC3'. The T7 promoter sequence is underlined and the T3 promoter is in bold. dsRNA was synthesized from the templates with T7 RNA polymerase (MEGAscript Kit, Ambion). As a control, we also synthesized dsRNA from a GFP cDNA fragment [679-1398 of pEGFP-N1 vector (Clontech) (accession No. = U556762)]. Approximately $0.1 \mathrm{nl}$ of dsRNA solution ( $3 \mathrm{ng} / \mathrm{nl}$ in distilled water) was injected into the poster region of cleavage embryos (stage 2). The injected embryos were allowed to

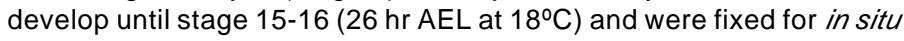
hybridization.

\section{$R T-P C R$ analysis}

The dsRNA-injected embryos were allowed to develop until stage 3$4\left(2 \mathrm{hr} \mathrm{AEL}\right.$ at $18^{\circ} \mathrm{C}$ ). Total RNA was isolated from 30 of the injected embryos using the RNeasy Mini Kit (QIAGEN). First-strand cDNA was synthesized from the RNA using oligo dT primer and SuperScript III RT (Invitrogen). Pairs of primers used for detecting bip2, ovo, Tif-IA, CG31716, Trf2, I(2)NC136 and RpL32 are listed in Supplementary Table S3. The thermal cycling condition was as follow: 1 cycle of $94^{\circ} \mathrm{C}$ for 5 minutes, then 30 cycles of $94^{\circ} \mathrm{C}$ for 15 seconds, $60^{\circ} \mathrm{C}$ for 30 seconds, $68^{\circ} \mathrm{C}$ for 1 minute. RpL32 was used as a control.

\section{$\beta$-gal expression in pole cells of dsRNA-injected embryos}

The embryos produced from nosGal4:VP16females (Van Doren et al., 1998) crossed with UAS-lacZ males were used as recipients for dsRNA microinjection. Microinjection of dsRNA and in situ hybridization using the $\beta-g a /$ probe were carried out as described above.

\section{Acknowledgements}

We thank Dr. K. Morohashi for providing the lacZ cDNA. We are grateful to Ms. Y. Ueda for her excellent technical assistance and to the members in our laboratory for their valuable comments. This work was supported in part by a grant from the Ministry of Education, Culture, 
Sports, Science and Technology, by a grant from the Mitsubishi Foundation, and by a Core Research for Evolutional Science and Technology (CREST) project of the Japan Science and Technology Agency.

\section{References}

AKASAKA, T., KLINEDINST, S., OCORR, K., BUSTAMANTE, E.L., KIM, S.K. and BODMER, R. (2006). The ATP-sensitive potassium (KATP) channel-encoded dSUR gene is required for Drosophila heart function and is regulated by tinman. Proc Natl Acad Sci USA 103: 11999-2004.

ANDREWS, J., GARCIA-ESTEFANIA, D., DELON, I., LÜ, J., MÉVEL-NINIO, M., SPIERER, A., PAYRE, F., PAULI, D. and OLIVER, B. (2000). OVO transcription factors function antagonistically in the Drosophila female germline. Development 127: 881-92.

ASAOKA-TAGUCHI, M., YAMADA, M., NAKAMURA, A., HANYU, K. and KOBAYASHI, S. (1999). Maternal Pumilio acts together with Nanos in germline development in Drosophila embryos. Nat Cel/ Bio/1: 431-7.

BEAMS, H.W. and KESSEL, R.G. (1974). The problem of germ cell determinants. Int Rev Cyto/39: 413-79.

BELL, B. and TORA, L. (1999). Regulation of gene expression by multiple forms of TFIID and other novel TAFII-containing complexes. Exp Cell Res 246: 11-9.

BIELINSKA, B., LÜ, J., STURGILL, D. and OLIVER, B. (2005). Core promoter sequences contribute to ovo-B regulation in the Drosophila melanogaster germline. Genetics 169: 161-72.

BROWN, N.H. and KAFATOS, F.C. (1988). Functional cDNA libraries from Drosophila embryos. J Mol Bio/203: 425-37.

BURKE, T.W. and KADONAGA, J.T. (1997). The downstream core promoter element, DPE, is conserved from Drosophila to humans and is recognized by TAFII60 of Drosophila. Genes Dev 11: 3020-31.

CAMPOS-ORTEGA, J.A. and HARTENSTEIN, V.E. (1997). The embryonic development of Drosophila melanogaster. Springer-Verlag, Heidelberg.

COLLART, M.A. (2003). Global control of gene expression in yeast by the Ccr4-Not complex. Gene 313: 1-16.

COUDERC, J.L., GODT, D., ZOLLMAN, S., CHEN, J., LI, M., TIONG, S., CRAMTON, S.E., SAHUT-BARNOLA, I. and LASKI, F.A. (2002). The bric à brac locus consists of two paralogous genes encoding BTB/POZ domain proteins and acts as a homeotic and morphogenetic regulator of imaginal development in Drosophila. Development 129: 2419-33.

DELON, I., CHANUT-DELALANDE, H. and PAYRE, F. (2003). The Ovo/Shavenbaby transcription factor specifies actin remodelling during epidermal differentiation in Drosophila. Mech Dev 120: 747-58.

DELUEN, C., JAMES, N., MAILLET, L., MOLINETE, M., THEILER, G., LEMAIRE, M., PAQUET, N. and COLLART, M.A. (2002). The Ccr4-not complex and yTAF1 (yTaf(II)130p/yTaf(II)145p) show physical and functional interactions. Mo/ Cel/ Bio/22: 6735-49.

DIETZL, G., CHEN, D., SCHNORRER, F., SU, K.C., BARINOVA, Y., FELLNER, M., GASSER, B., KINSEY, K., OPPEL, S., SCHEIBLAUER, S. et al. (2007). A genome-wide transgenic RNAi library for conditional gene inactivation in Drosophila. Nature 448: 151-6

EDDY, E.M. (1975). Germ plasm and the differentiation of the germ cell line. Int Rev Cyto/43: 229-80.

EXTAVOUR, C.G. and AKAM, M. (2003). Mechanisms of germ cell specification across the metazoans: epigenesis and preformation. Development 130: 586984.

FATCHIYAH, ZUBAIR, M., SHIMA, Y., OKA, S., ISHIHARA, S., FUKUI-KATOH, Y. and MOROHASHI, K. (2006). Differential gene dosage effects of Ad4BP/SF-1 on target tissue development. Biochem Biophys Res Commun 341: 1036-45.

GRUMMT, I. (2003). Life on a planet of its own: regulation of RNA polymerase I transcription in the nucleolus. Genes Dev 17: 1691-702.

HAY, B., ACKERMAN, L., BARBEL, S., JAN, L.Y. and JAN, Y.N. (1988a). Identification of a component of Drosophila polar granules. Development 103: 625-40.

HAY, B., JAN, L.Y. and JAN, Y.N. (1988b). A protein component of Drosophila polar granules is encoded by vasa and has extensive sequence similarity to ATPdependent helicases. Cel/55: 577-87.
HAYASHI, Y., HAYASHI, M. and KOBAYASHI, S. (2004). Nanos suppresses somatic cell fate in Drosophila germ line. Proc Nat/ Acad Sci USA 101: 1033842.

HOCHHEIMER, A., ZHOU, S., ZHENG, S., HOLMES, M.C. and TJIAN, R. (2002). TRF2 associates with DREF and directs promoter-selective gene expression in Drosophila. Nature 420: 439-45.

IIDA, T. and KOBAYASHI, S. (1998). Essential role of mitochondrially encoded large rRNA for germ-line formation in Drosophila embryos. Proc Nat/ Acad SCi USA 95: 11274-8.

KADYROVA, L.Y., HABARA, Y., LEE, T.H. and WHARTON, R.P. (2007). Translational control of maternal Cyclin B mRNA by Nanos in the Drosophila germline. Development 134: 1519-27.

KOBAYASHI, M., MICHAUT, L., INO, A., HONJO, K., NAKAJIMA, T., MARUYAMA, Y., MOCHIZUKI, H., ANDO, M., GHANGREKAR, I., TAKAHASHI, K. et al. (2006). Differential microarray analysis of Drosophila mushroom body transcripts using chemical ablation. Proc Natl Acad Sci USA 103: 14417-22.

KOPYTOVA, D.V., KRASNOV, A.N., KOPANTCEVA, M.R., NABIROCHKINA, E.N., NIKOLENKO, J.V., MAKSIMENKO, O., KURSHAKOVA, M.M., LEBEDEVA, L.A., YEROKHIN, M.M., SIMONOVA, O.B. et al. (2006). Two isoforms of Drosophila TRF2 are involved in embryonic development, premeiotic chromatin condensation, and proper differentiation of germ cells of both sexes. Mo/ Cell Bio/26: 7492-505.

KUNWAR, P.S., STARZ-GAIANO, M., BAINTON, R.J., HEBERLEIN, U. and LEHMANN, R. (2003). Tre1, a G protein-coupled receptor, directs transepithelial migration of Drosophila germ cells. PLOS Bio/1: E80.

LASKO, P.F. and ASHBURNER, M. (1990). Posterior localization of vasa protein correlates with, but is not sufficient for, pole cell development. Genes Dev 4: 905-21.

LAWSON, K.A., DUNN, N.R., ROELEN, B.A., ZEINSTRA, L.M., DAVIS, A.M., WRIGHT, C.V., KORVING, J.P. and HOGAN, B.L. (1999). Bmp4 is required for the generation of primordial germ cells in the mouse embryo. Genes Dev 13: 424-36.

LÉCUYER, E., YOSHIDA, H., PARTHASARATHY, N., ALM, C., BABAK, T., CEROVINA, T., HUGHES, T.R., TOMANCAK, P. and KRAUSE, H.M. (2007). Global analysis of mRNA localization reveals a prominent role in organizing cellular architecture and function. Cel/131: 174-87.

LÜ, J. and OLIVER, B. (2001). Drosophila OVO regulates ovarian tumor transcription by binding unusually near the transcription start site. Development 128 : 1671-86.

MAHOWALD, A.P. (2001). Assembly of the Drosophila germ plasm. Int Rev Cytol 203: $187-213$.

MARTINHO, R.G., KUNWAR, P.S., CASANOVA, J. and LEHMANN, R. (2004). A noncoding RNA is required for the repression of RNApolll-dependent transcription in primordial germ cells. Curr Biol 14: 159-65.

MÉVEL-NINIO, M., TERRACOL, R. and KAFATOS, F.C. (1991). The ovo gene of Drosophila encodes a zinc finger protein required for female germ line development. EMBO J10: 2259-66.

MORRIS, J.Z., HONG, A., LILLY, M.A. and LEHMANN, R. (2005). twin, a CCR4 homolog, regulates cyclin poly $(A)$ tail length to permit Drosophila oogenesis. Development 132: 1165-74.

MOSS, T. and STEFANOVSKY, V.Y. (2002). At the center of eukaryotic life. Cell 109: 545-8.

MUKAI, M., KITADATE, Y., ARITA, K., SHIGENOBU, S. and KOBAYASHI, S. (2006). Expression of meiotic genes in the germline progenitors of Drosophila embryos. Gene Expr Patterns 6: 256-66.

NAKAMURA, A., AMIKURA, R., MUKAI, M., KOBAYASHI, S. and LASKO, P.F. (1996). Requirement for a noncoding RNA in Drosophila polar granules for germ cell establishment. Science 274: 2075-9.

OLIVER, B., PERRIMON, N. and MAHOWALD, A.P. (1987). The ovo locus is required for sex-specific germ line maintenance in Drosophila. Genes Dev 1: 913-23.

PAYRE, F., VINCENT, A. and CARRENO, S. (1999). ovo/svb integrates Wingless and DER pathways to control epidermis differentiation. Nature 400: 271-5.

POINTUD, J.C., LARSSON, J., DASTUGUE, B. and COUDERC, J.L. (2001). The $\mathrm{BTB} / \mathrm{POZ}$ domain of the regulatory proteins Bric à brac 1 ( $\mathrm{BAB} 1$ ) and Bric à brac 2 (BAB2) interacts with the novel Drosophila TAF(II) factor BIP2/dTAF(II)155. 
Dev Bio/237: 368-80.

RABENSTEIN, M.D., ZHOU, S., LIS, J.T. and TJIAN, R. (1999). TATA box-binding protein (TBP)-related factor 2 (TRF2), a third member of the TBP family. Proc Nat/ Acad Sci USA 96: 4791-6.

ROBERTSON, S.E., DOCKENDORFF, T.C., LEATHERMAN, J.L., FAULKNER, D.L. and JONGENS, T.A. (1999). germ cell-less is required only during the establishment of the germ cell lineage of Drosophila and has activities which are dependent and independent of its localization to the nuclear envelope. Dev Biol 215: 288-97.

RONGO, C. and LEHMANN, R. (1996). Regulated synthesis, transport and assembly of the Drosophila germ plasm. Trends Genet 12: 102-9.

SANO, H., MUKAI, M. and KOBAYASHI, S. (2001). Maternal Nanos and Pumilio regulate zygotic vasa expression autonomously in the germ-line progenitors of Drosophila melanogaster embryos. Dev Growth Differ 43: 545-52.

SATO, K., HAYASHI, Y., NINOMIYA, Y., SHIGENOBU, S., ARITA, K., MUKAI, M. and KOBAYASHI, S. (2007). Maternal Nanos represses hid/skl-dependent apoptosis to maintain the germ line in Drosophila embryos. Proc Natl Acad SCl USA 104: 7455-60.

SEYDOUX, G. and DUNN, M.A. (1997). Transcriptionally repressed germ cells lack a subpopulation of phosphorylated RNA polymerase II in early embryos of Caenorhabditis elegans and Drosophila melanogaster. Development 124: 2191-201.

SHIGENOBU, S., ARITA, K., KITADATE, Y., NODA, C. and KOBAYASHI, S. (2006). Isolation of germline cells from Drosophila embryos by flow cytometry. Dev Growth Differ 48: 49-57.

SONODA, J. and WHARTON, R.P. (2001). Drosophila Brain Tumor is a translational repressor. Genes Dev 15: 762-73.

STAAB, S. and STEINMANN-ZWICKY, M. (1996). Female germ cells of Drosophila require zygotic ovo and otu product for survival in larvae and pupae respectively. Mech Dev 54: 205-10.

SZUPERÁK, M., ZVARA, A. and ERDÉLYI, M. (2005). Identification of germ plasmenriched mRNAs in Drosophila melanogaster by the cDNA microarray tech- nique. Gene Expr Patterns 5: 717-23.

TJIAN, R. and MANIATIS, T. (1994). Transcriptional activation: a complex puzzle with few easy pieces. Cel/77: 5-8.

TOMANCAK, P., BEATON, A., WEISZMANN, R., KWAN, E., SHU, S., LEWIS, S.E., RICHARDS, S., ASHBURNER, M., HARTENSTEIN, V., CELNIKER, S.E. et al. (2002). Systematic determination of patterns of gene expression during Drosophila embryogenesis. Genome Bio/3: RESEARCH0088.

VAN DOREN, M., WILLIAMSON, A.L. and LEHMANN, R. (1998). Regulation of zygotic gene expression in Drosophila primordial germ cells. Curr Bio/8: 2436.

VERRIJZER, C.P., YOKOMORI, K., CHEN, J.L. and TJIAN, R. (1994). Drosophila TAFII150: similarity to yeast gene TSM-1 and specific binding to core promoter DNA. Science 264: 933-41.

WHARTON, R.P. and AGGARWAL, A.K. (2006). mRNA regulation by Puf domain proteins. Sci STKE2006: pe37.

WIESCHAUS, E., NÜSSLEIN-VOLHARD, C. and JÜRGENS, G. (1984). Mutations Affecting the Pattern of the Larval Cuticle in Drosophila-Melanogaster.III. Zygotic Loci on the X-Chromosome and fourth Chromosome. Wilhelm Rouxs Archives of Developmental Biology 193: 296-307.

XIAO, L., KIM, M. and DEJONG, J. (2006). Developmental and cell type-specific regulation of core promoter transcription factors in germ cells of frogs and mice. Gene Expr Patterns 6: 409-19.

YANG, Y., GEHRKE, S., IMAI, Y., HUANG, Z., OUYANG, Y., WANG, J.W., YANG, L., BEAL, M.F., VOGEL, H. and LÜ, B. (2006). Mitochondrial pathology and muscle and dopaminergic neuron degeneration caused by inactivation of Drosophila Pink1 is rescued by Parkin. Proc Nat/ Acad Sci USA 103: 10793-8.

ZALOKAR, M. (1976). Autoradiographic study of protein and RNA formation during early development of Drosophila eggs. Dev Bio/49: 425-37.

ZHANG, D., PENTTILA, T.L., MORRIS, P.L., TEICHMANN, M. and ROEDER, R.G. (2001). Spermiogenesis deficiency in mice lacking the Trf2 gene. Science292: 1153-5. 


\section{Further Related Reading, published previously in the Int. J. Dev. Biol.}

See our Special Issue Fertilization in honor of David Garbers and edited by P.M. Wassarman and V.D. Vacquier at:

http://www.ijdb.ehu.es/web/contents.php?vol=52\&issue=5/6

See our Special Issue Developmental Biology in Poland edited by Tarkowski, Maleszewski and Kloc at:

http://www.ijdb.ehu.es/web/contents.php?vol=52\&issue=2-3

Identification and gene expression of versican during early development of Xenopus

Paola Casini, Michela Ori, Angela Avenoso, Angela D’Ascola, Paola Traina, Walter Mattina, Roberto Perris, Giuseppe M. Campo, Alberto Calatroni, Irma Nardi and Salvatore Campo

Int. J. Dev. Biol. (2008) 52: doi: 10.1387/ijdb.082582pc

Basic Science B.D. (before Drosophila): Cytology at Warsaw University (Poland)

Malgorzata Kloc

Int. J. Dev. Biol. (2008) 52: 115-119

Hypomethylation of paternal DNA in the late mouse zygote is not essential for development Zbigniew Polanski, Nami Motosugi, Chizuko Tsurumi, Takashi Hiiragi and Steffen Hoffmann Int. J. Dev. Biol. (2008) 52: 295-298

Regionalized calcium signaling in zebrafish fertilization

Dipika Sharma and William H. Kinsey

Int. J. Dev. Biol. (2008) 52: 561-570

Embryonic development of the proepicardium and coronary vessels

Anna Ratajska, Elzbieta Czarnowska and Bogdan Ciszek

Int. J. Dev. Biol. (2008) 52: 229-236

Molecular aspects of avian oogenesis and fertilisation

Bozenna Olszanska and Urszula Stepinska

Int. J. Dev. Biol. (2008) 52: 187-194

Centroid, a novel putative DEAD-box RNA helicase maternal mRNA, is localized in the mitochondrial cloud in Xenopus laevis oocytes

Malgorzata Kloc and Agnes P. Chan

Int. J. Dev. Biol. (2007) 51: 701-706

Drosophila Mrityu encodes a BTB/POZ domain-containing protein and is expressed dynamically during development

Jamie C. Rusconi and Uma Challa

Int. J. Dev. Biol. (2007) 51: 259-263

Germ-plasm specification and germline development in the parthenogenetic pea aphid Acyrthosiphon pisum: Vasa and Nanos as markers

Chun-che Chang, Wen-chih Lee, Charles E. Cook, Gee-way Lin and Tschining Chang Int. J. Dev. Biol. (2006) 50: 413-421

Differences in maternal supply and early development of closely related nematode species

Magdalena Laugsch and Einhard Schierenberg

2006 ISI **Impact Factor $=3.577^{* *}$

Int. J. Dev. Biol. (2004) 48: 655-662

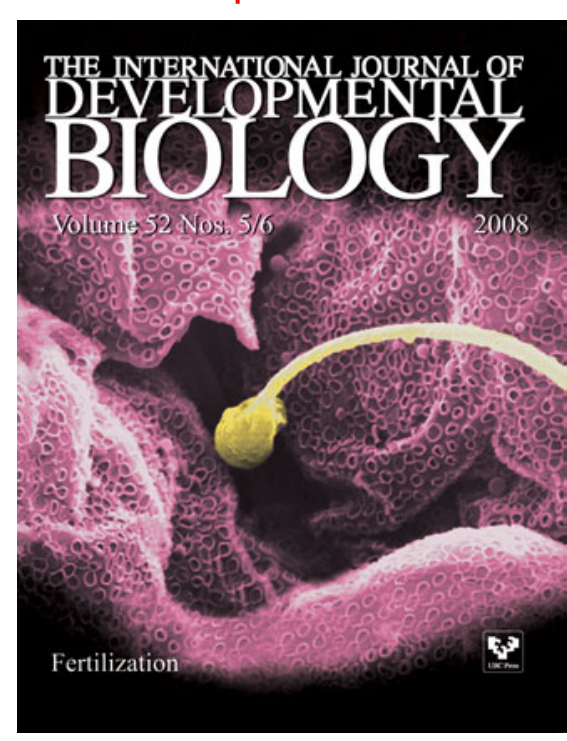

